\title{
SUATU MODEL MATEMATIKA INTERAKSI SEL KANKER NASOFARING DENGAN VIRUS EPSTEIN-BARR (EBV) DENGAN INTERVENSI KEMOTERAPI
}

\author{
SAHRUL AHMAD, YUDI ARI ADI \\ Program Studi Matematika, \\ Fakultas Sain dan Teknologi Terapan, Universitas Ahmad Dahlan, \\ Yogyakarta, Indonesiaemail : sahrul1600015093@webmail.uad.ac.id,yudi.adi@math.uad.ac.id
}

Diterima 4 Agustus $2021 \quad$ Direvisi 15 September $2021 \quad$ Dipublikasikan 21 Oktober 2021

\begin{abstract}
Abstrak. Kanker nasofaring (KNF) merupakan kanker yang berasal dari sel epitel nasofaring yang berada di rongga belakang hidung dan di belakang langit-langit rongga mulut. Karsinoma nasofaring sangat erat kaitannya dengan infeksi Epstein Barr Virus (EBV). Pengobatan kanker nasofaring dapat ditempuh memlaui berbagai cara, seperti operasi atau pembedahan, radioterapi, kemoterapi, terapi hormon, dan imunoterapi. Pada makalah ini disusun model matematika perkembangan sel nasofaring akibat infeksi virus EBV dengan intervensi kemoterapi. Model berbentuk sistem persamaan diferensial biasa berdimensi empat yang mendeskripsikan interaksi sel sehat, virus, sel terinfeksi, dan sel karsinoma invasif. Selanjutnya dibahas eksistensi dan analisis kestabilan lokal dari titik ekuilibrium yang menunjukkan bahwa tingkat infeksi dan intervensi pengobatan merupakan faktor penting dalam perkembangan kanker nasofaring. Simulasi numerik diberikan untuk memverifikasi teorema yang diperoleh.
\end{abstract}

Kata Kunci: Kanker nasofaring, model matematika, kestabilan lokal

\section{Pendahuluan}

Karsinoma nasofaring (KNF) merupakan tumor yang tumbuh dari sel epitel yang melapisi permukaan nasofaring, khususnya fossa Rosenmuller [1]. Pertumbuhan tumor tersebut dapat meluas ke nasofaring, dan dapat bermestastasis ke kelenjer getah bening servikal, dan juga bermestastasis jauh ke tulang, paru-paru, serta mediastinum. KNF merupakan penyakit dengan etiologi multifaktorial, yang di antaranya dihubungkan dengan infeksi virus Epstein-Barr (EBV). KNF mempunyai distribusi geografis dan etnis yang luar biasa dengan disertai interaksi faktor genetik, virus, lingkugan dan diet. Di dunia, terdapat perkiraan insiden kasus KNF sebanyak 87.000, serta 51.000 kematian pada tahun 2012, yang mewakili sekitar $0,7 \%$ dari beban kanker secara global [2]. Kanker ini dianggap sebagai salah satu yang jarang

${ }^{*}$ penulis korespondensi 
terjadi secara global, berada pada urutan 24 di antara berbagai kanker yang paling sering terdiagnosis di dunia dan pada urutan 22 di negara berkembang. KNF 2-3 kali lipat lebih sering terjadi pada pria dibandingkan pada wanita. KNF diperkirakan mewakili $2 \%$ dari seluruh karsinoma sel skuamosa kepada leher, dengan angka kejadiana 0,5-2 per 100.000 populasi di Amerika Serikat, tetapi penyakit ini endemik pada daerah geografis seperti Cina Selatan, Asia Tenggara, Indonesia, Jepang, dan Afrika Utara, serta pada orang Eksimo. Indoneisa merupakan negara kedua dengan insidens KNF terbanyak. Di Indonesia, KNF mempunyai insidens sebanyak 13.000, dengan angka kejadian sebanyak 6,2 per 100.000 [3]. Insidensi KNF di Indonesia pada tahun 2018 sebesar 17.992 yang didominasi oleh pria sebesar 13.966 kasus [4]. Infeksi virus Epstein Barr dan keterlibatan genetik masih menjadi penyebab utama dari KNF. Selain potensi perubahan genetik dari infeksi EBV, adanya infeksi laten pada sel epitel tampaknya berperan besar dalam perkembangan KNF [8].

Penanggulangan kanker nasofaring saat ini masih menjadi suatu masalah. Letak nasofaring yang tersembunyi dan tidak ada gejala yang spesifik yang dijumpai pada penderita kanker nasofaring menyebabkan banyak kasus yang sulit dideteksi $[4,5,6]$. Ada beberapa cara untuk mengobati kanker nasofaring seperti operasi atau pembedahan, radioterapi, kemoterapi, terapi hormon, dan imunoterapi. Metode pengobatan yang digunakan penelitian ini adalah kemoterapi, dimana kemoterapi itu sendiri menggunakan pemberian satu atau lebih obat yang ditunjukkan untuk menghambat, mengurangi maupun membunuh pertumbuhan sel kanker. Namun demikian, kemoterapi juga dapat menghambat pertumbuhan sel sehat yang berdampak pada kinerja dari sel tersebut.

Beberapa model matematika pada kanker nasofaring telah disusun, seperti dalam $[5,7,9]$. Namun pada model-model tersebut belum melibatkan interaksi virus dan intervensi pengobatan kemoterapi. Pada penelitian ini digunakan persamaan logistik untuk menggambarkan pertumbuhan sel sehat, virus, sel infeksi, karsinoma invasive dan pengaruh pengobatan kemoterapi. Penelitian ini sangat bermanfaat bagi dunia medis sebagai pertimbangan dalam memberikan pengobatan yang tepat bagi penderita kanker nasofaring sehingga angka kematian akibat kanker nasofaring dapat ditekan.

Artikel ini disusun sebagai berikut. Pada Bagian 2 disajikan beberapa teori yang mendasari pemodelan. Selanjutnya pada Bagian 3 dibahas formulasi model dan sifat solusinya, eksistensi dan analisis kestabilan titik ekuilibrium, serta simulasi numerik. Artikel ini diakhiri dengan kesimpulan di Bagian 4.

\section{Landasan Teori}

Pada bagian ini akan diberikan beberapa definisi dan teorema yang akan digunakan dalam pembahasan sistem persamaan diferensial. Sistem yang dibahas pada subbab ini dalah sistem persamaan diferensial nonlinear autonomous sebagai berikut:

$$
\dot{\mathbf{x}}=f(\mathbf{x}), \mathbf{x}\left(t_{0}\right)=\mathbf{x}_{0},
$$

dengan $\mathbf{f}: E \rightarrow \mathbb{R}^{n}, E$ himpunan terbuka, $E \in \mathbb{R}^{n}$.

Sistem (2.1) dikatakan linear jika $f_{i}: \mathbb{R}^{n} \rightarrow \mathbb{R}$ linier jika $\mathbf{f}=\left[f_{1}, f_{2}, \cdots, f_{n}\right]$ untuk setiap $i$. Jika tidak maka Sistem (2.1) dikatakan nonlinear. Selanjutnya,akan 
dibahas metode linearisasi sistem nonlinear untuk menyelidiki kestabilan titik ekuilibrium. Misalkan $\overline{\mathbf{x}}$ adalah titik ekuilibrium sistem nonlinear $\dot{\mathbf{x}}=f(\mathbf{x})$ dan

$$
J f(\overline{\mathbf{x}})=\left[\begin{array}{cccc}
\frac{\partial f_{1}}{\partial x_{1}}(\overline{\mathbf{x}}) & \frac{\partial f_{1}}{\partial x_{2}}(\overline{\mathbf{x}}) & \cdots & \frac{\partial f_{1}}{\partial x_{n}}(\overline{\mathbf{x}}) \\
\frac{\partial f_{2}}{\partial x_{1}}(\overline{\mathbf{x}}) & \frac{\partial f_{2}}{\partial x_{2}}(\overline{\mathbf{x}}) & \cdots & \frac{\partial f_{2}}{\partial x_{n}}(\overline{\mathbf{x}}) \\
\vdots & \vdots & \ddots & \vdots \\
\frac{\partial f_{n}}{\partial x_{1}}(\overline{\mathbf{x}}) & \frac{\partial f_{n}}{\partial x_{2}}(\overline{\mathbf{x}}) & \cdots & \frac{\partial f_{n}}{\partial x_{n}}(\overline{\mathbf{x}}),
\end{array}\right]
$$

adalah matriks Jacobian dari fungsi $\mathbf{f}: \mathbb{R}^{n} \rightarrow \mathbb{R}^{n}$. Linearisasi sistem diberikan dalam definisi berikut.

Definisi 2.1. [11] Sistem linier $\dot{\boldsymbol{x}}=$ Ax dengan matriks $A=J f(\overline{\boldsymbol{x}})$ disebut linearisasi $\dot{\boldsymbol{x}}=f(\boldsymbol{x})$ pada $\overline{\boldsymbol{x}}$.

Definisi 2.2. [11] Misalkan $E \in \mathbb{R}^{n}$ dan $f: E \rightarrow \mathbb{R}^{n}$. Titik $\overline{\boldsymbol{x}} \in E$ disebut titik ekuilibrium sistem (2.1) jika $f(\overline{\boldsymbol{x}})=0$.

Kestabilan titik ekuilibrium Sistem (??) diberikan dalam definisi berikut.

Definisi 2.3. [11] Misalkan $f: E \rightarrow \mathbb{R}^{n}, E \subseteq \mathbb{R}^{n}$. Titik ekuilibrium $\overline{\boldsymbol{x}}$ dari Sistem (2.1) dikatakan:

(i) stabil, jika untuk setiap $\varepsilon>0$ terdapat $\delta>0$ sedemikian hingga untuk setiap $t \geq t_{0}$ dan $\left\|x_{0}-\overline{\boldsymbol{x}}\right\| \leq \delta$ berakibat $\|x(t)-\overline{\boldsymbol{x}}\|<\varepsilon$.

(ii) tidak stabil, jika tidak memenuhi (1).

(iii) stabil asimtotik, jika stabil dan terdapat $\eta>0$ sedemikian sehingga untuk setiap $\left\|x_{0}-\overline{\boldsymbol{x}}\right\| \leq$ eta berakibat $\lim _{t \rightarrow \infty} x(t)=\overline{\boldsymbol{x}}$.

Jenis titik ekuilibrium $\overline{\mathbf{x}}$ dapat ditentukan melalui nilai eigen dari matriks Jacobian $D f(\overline{\mathbf{x}})$ yang diberikan dalam teorema berikut.

Teorema 2.4. [11] Misalkan $\overline{\boldsymbol{x}}$ adalah titik ekuilibrium hiperbolik. Diberikan matriks Jacobian dari Sistem (2.1), $D f(\overline{\boldsymbol{x}})$ berukuran $n \times n$ dengan nilai eigen $\lambda_{i}$, $i=1,2, \cdots, k, k \leq n$.

(i) Jika $\operatorname{Re}\left({ }_{i}\right)<0$ untuk $i=1,2, \cdots, k$ maka titik ekuilibrium $\overline{\boldsymbol{x}}$ stabil asimtotik lokal.

(ii) Jika terdapat $i$, dengan $\operatorname{Re}\left({ }_{i}\right)>0$, maka titik ekuilibrium $\overline{\boldsymbol{x}}$ tidak stabil.

\section{Pembahasan}

\subsection{Formulasi Model}

Model matematika yang dibahas pada artikel ini melibatkan sel sehat orofaringeal dan sel orofaringeal yang terinfeksi virus Epstein-Barr sehingga menjadi karsinoma invasif atau yang biasa dikenal dengan kanker nasofaring. Dalam pembahasan ini diamati perkembangan kanker nasofaring mulai dari sel sehat yang terinfeksi menjadi karsinoma invasif, dengan interaksi obat kemoterapi. Dalam pemodelan ini, 
diperhatikan empat kelompok populasi, yaitu sel sehat (S), sel terinfeksi (I), karsinoma invasif (C), Virus (V). Diasumsikan bahwa laju pertumbuhan sel sehat dan laju infeksi mengikuti model logistik, dan pemberian kemoterapi tidak hanya membunuh sel-sel karsioma invasif tetapi juga menyerang sel-sel sehat. Adapun dosis obat untuk kemoterapi diasumsikan konstan. Skema interaksi sel sehat, sel infeksi, karsinoma invasif dan virus dengan pemberian pengobatan kemoterapi disajikan dalam diagram kompertemen pada Gambar 1.

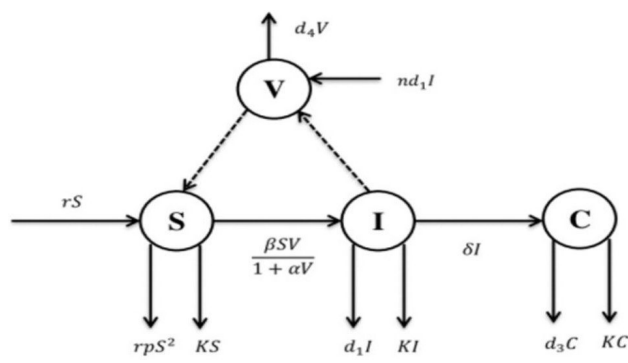

Gambar 1: Skema perkembangan Kanker Nasofaring

Berdasarkan skema pada Gambar 1 model interaksi sel sehat, sel infeksi, karsinoma invasif dan virus dengan pemberian kemoterapi dapat disajikan dalam sistem persamaan diferensial nonlinier sebagai berikut:

$$
\begin{aligned}
\frac{d S}{d t} & =r(1 p S) S \frac{\beta_{2} S V}{1+\alpha V} K S, \\
\frac{d I}{d t} & =\frac{\beta_{2} S V}{1+\alpha V}\left(d_{1}+\delta+K\right) I, \\
\frac{d C}{d t} & =\delta I-\left(d_{3}+K\right) C, \\
\frac{d V}{d t} & =n d_{1} I-d_{4} V .
\end{aligned}
$$

yang memenuhi kondisi awal

$$
S(0), I(0), C(0), V(0) \geq 0,
$$

dengan
$S$ : Jumlah populasi sel sehat,
$I$ : Jumlah populasi sel terinfeksi,
$C$ : Jumlah populasi karsinoma invasif,
$V$ : Jumlah populasi virus,
$K$ : Dosis obat kemoterapi. 
$r$ : Laju pertumbuhan sel sehat,

$\alpha$ : Laju penghambat,

$p$ : Laju tingkat kematian alami sel sehat,

$\beta$ : Laju pertumbuhan sel infeksi,

$\delta$ : Laju pertumbuhan sel infeksi ke karsinoma invasif,

$d_{1}$ : Laju tingkat kematian alami sel infeksi,

$d_{3}$ : Laju tingkat kematian alami karsinoma invasif,

$d_{4}$ : Laju kematian alami virus,

$n$ : Laju pertumbuhan virus.

Pada model (3.1), jumlah populasi sel sehat, $S$ akan bertambah mengikuti model logistik, dengan laju pertumbuhan sebesar $r$ dan kapasitas maksimumnya adalah $\frac{1}{p}$. Sel sehat yang tidak terinfeksi akan menjadi infeksi pada tingkat kejenuhan $\frac{\beta S V}{1+\alpha V}$, dengan $\beta$ adalah laju pertumbuhan infeksi maksimal, sedangkan $1+\alpha V$ adalah efek penghambatan. Adapun jumlah sel sehat dapat berkurang karena adanya interaksi dengan obat kemoterapi yang menyebabkan kematian pada sel sehat dengan dosis obat sebesar $K$. Di dalam sel sehat yang terinfeksi, yang disebabkan oleh virus Epstein-Bar yang akan berkembiang biak hingga batas dimana sel sehat akan menjadi karsinoma invasif, diikuti dengan sel sehat yang baru terinfeksi dengan laju pertumbuhan virus $n$. Parameter $d_{1}$ adalah tingkat kematian alami sel yang terinfeksi, $\delta$ adalah laju pertumbuhan, dan $d_{4}$ adalah tingkat kematian alami virus.

Selanjutnya agar sistem (3.1) memiliki makna secara biologi, maka perlu ditunjukkan kepositifan dan keterbatasan solusinya. Keterbatasan diberikan dalam Teorema berikut.

Teorema 3.1. Untuk setiap kondisi awal $S(0) \geq 0, I(0) \geq 0, C(0) \geq 0, V(0) \geq 0$, maka solusi model (3.1) selalu nonnegatif untuk setiap $t>0$.

Bukti. Dari model (3.1) diperoleh:

$$
\begin{aligned}
S(t) & : S(0) e^{\int_{0}^{t}\left(r(1-p S(\tau))-\frac{\beta V(\tau)}{1+\alpha V(\tau)-K}\right.} \geq 0, \\
I(t) & \geq I(0) e^{-\int_{0}^{t}\left(d_{1}+\delta+K\right)} \geq 0, \\
C(t) & \geq C(0) e^{-\int_{0}^{t}\left(d_{3}+K\right)} \geq 0, \\
v(t) & \geq V(0) e^{-\int_{0}^{t} d_{4}} \geq 0 .
\end{aligned}
$$

Dengan demikian $S(t) \geq 0, I(t) \geq 0, C(t) \geq 0, V(t) \geq 0$ untuk setiap $t \geq 0$.

Teorema 3.2. Solusi model (3.1) terbatas untuk setiap $t>0$.

Bukti. Akan ditunjukkan terdapat $M>0$ sehingga $S(t) \leq M, I(t) \leq M, C(t) \leq$ $M, V(t) \leq M$ untuk setiap $t>0$. Dari persamaan pertama model (3.1) diperoleh:

$$
\frac{d S}{d t} \leq r(1-p S) S
$$


504 Sahrul Ahmad, Yudi Ari Adi

sehingga diperoleh

$$
\lim _{t \rightarrow \infty} \sup S(t) \leq \frac{1}{p}=M_{1} .
$$

Selanjutnya, dari model (3.1), total populasi sel adalah $N_{1}=S+I+C$, sehingga diperoleh

$$
\frac{d N_{1}}{d t}=r(1-p S) S-d_{1} I-d_{3} C-K N_{1} \leq r S-K N_{1} .
$$

Karena $S \leq \frac{1}{p}$, maka

$$
\frac{d N_{1}}{d t} \leq r \frac{1}{p}-K N_{1}
$$

sehingga

$$
N_{1} \leq \frac{r}{p K}=M_{2} .
$$

Dengan demikian, $I(t) \leq M_{2}$ dan $C(t) \leq M_{2}$. Dari persamaan keempat diperoleh

$$
\frac{d V}{d t}=d_{1} n I-d_{4} V \leq n d_{1} M_{2}-d_{4} V
$$

sehingga diperoleh

$$
V \leq n d_{1} M_{2}=M_{3} .
$$

Jadi terdapat $M=\max \left\{M_{1}, M_{2}, M_{3}\right\}$ sehingga $S(t) \leq M, I(t) \leq M, C(t) \leq M$, $V(t) \leq M$ untuk setiap $t>0$.

\subsection{Eksistensi dan kestabilan titik ekuilibrium}

Model (3.1) memiliki tiga titik ekuilibrium, yaitu:

(i) Titik ekuilibrium trivial $E_{0}=(0,0,0,0)$, yang secara medis tidak memiliki arti.

(ii) Titik ekulibrium bebas penyakit $E_{1}=\left(\frac{r-K}{r p}, 0,0,0\right)$, yang menunjukkan virus EBV lenyap dari tubuh sehingga tidak terjadi KNF. Titik ekuilibrium ini eksis untuk $r K>0$.

(iii) Titik ekulibrium KNF $E_{2}=\left(S^{*}, I^{*}, C^{*}, V^{*}\right)$, dengan

$$
\begin{aligned}
S^{*} & =\frac{(1+\alpha V)(r-K)-\beta V}{(1+\alpha V) p}, \\
I^{*} & =\frac{\beta V(1+\alpha V)(r-K)-\beta V}{p(1+\alpha V)^{2}\left(d_{1}+\delta+K\right)}, \\
C^{*} & =\frac{\alpha \beta V(1+\alpha V)(r-K)-\beta V}{p(1+\alpha V)^{2}\left(d_{1}+\delta+K\right)\left(d_{3}+K\right)} .
\end{aligned}
$$

dengan $V^{*}$ akar real positif dari

$$
a_{0} V^{2}+a_{1} V+a_{2}=0
$$


dengan

$$
\begin{aligned}
& a_{0}=d_{4} p \alpha^{2}\left(d_{1}+\delta+K\right), \\
& a_{1}=2\left(d_{4} p \alpha^{2}\left(d_{1}+\delta+K\right)\right) \alpha-n d_{1} \beta(\alpha(r-K)-\beta), \\
& a_{2}=d_{4} p \alpha^{2}\left(d_{1}+\delta+K\right)-n d_{1} \beta(r-K) .
\end{aligned}
$$

Titik ekuilibrium KNF eksis jika $a_{1}$ dan $a_{2}$ salah satu atau keduanya negatif. Jika eksis, titik ekuilibrium KNF, $E_{2}$ ini menunjukkan terjadinya kanker nasofaring.

Selanjutnya akan dilihat kestabilan lokal dari titik ekuilibrium $E_{1}$ dan $E_{2}$. Kestabilan lokal titik ekuilbrium ditentukan melalui nilai eigen matrik Jacobian model (3.1). Selengkapnya diberikan dalam teorema berikut.

Teorema 3.3. Titik ekuilibrium bebas kanker $E_{1}$ stabil asimtotik lokal jika

$$
\beta n d_{1}(K r)+d_{4} \operatorname{pr}\left(d_{1}+\alpha+K\right)>0 .
$$

Bukti. Matriks Jacobian sistem (3.1) di titik $E_{1}$ adalah

$$
J\left(E_{1}\right)=\left[\begin{array}{cccc}
-r+K & 0 & 0 & -\frac{\beta(r-K)}{r p} \\
0 & -\left(d_{1}+\delta+K\right) & 0 & \frac{\beta(r-K)}{r p} \\
0 & \delta & -\left(d_{3}+K\right) & 0 \\
0 & n d_{1} & 0 & -d_{4}
\end{array}\right]
$$

yang memiliki persamaan karakteristik berbentuk

$$
(\lambda+r K)\left(\lambda+d_{3}+K\right)\left(\lambda_{2}+c_{1} \lambda+c_{2}\right)=0,
$$

dengan

$$
\left.c_{1}=\left(d_{1}+d_{4}+\delta+K\right), c_{2}=\frac{\beta d_{1} n(K-r)}{r p}+d_{4}\left(d_{1}+\delta+K\right)\right)
$$

Mengingat $r-K>0$, maka akar-akar persamaan karakteristik persamaan (3.3) meiliki bagian real negatif jika $c_{2}>0$ atau $\left.\frac{\beta d_{1} n(K-r)}{r p}+d_{4}\left(d_{1}+\delta+K\right)\right)>0$. Dengan kata lain, terbukti bahwa $E_{1}$ stabil asimtotik lokal jika $\frac{\beta d_{1} n(K-r)}{r p}+$ $\left.d_{4}\left(d_{1}+\delta+K\right)\right)>0$.

Selanjutnya untuk menentukan kestabilan titik ekuilibrium kanker nasofaring, didefinisikan

$$
\begin{aligned}
M & =r-2 r p S^{*}-\frac{\beta V^{*}}{1+\alpha V^{*}}-K, \\
G & =d_{1}+\delta+K \\
H & =d_{3}+\delta+K+d_{4}, \\
a_{2} & =H-M, \\
a_{1} & =d_{4} G-H M-\beta S^{*}\left(1+\alpha V^{*}\right)\left(d_{1}+d_{4}\right), \\
a_{0} & =\frac{\beta S^{*}\left(1+\alpha V^{*}\right)\left(M n d_{1}-G d_{4}\right)+\beta^{2} n d_{1} S^{*} V^{*}}{1+V^{* 3} \alpha^{3}+3 V^{* 2} \alpha^{2}+3 V^{*} \alpha}-d_{4} G M .
\end{aligned}
$$


dan diperoleh teorema berikut.

Teorema 3.4. Titik ekuilibrium kanker nasofaring $E_{2}$ stabil asimtotik lokal jika $a_{2}, a_{1}, a_{0}>0$.

Bukti. Matriks Jacobian Sistem (3.1) di titik $E_{1}$ adalah

$$
J\left(E_{2}\right)=\left[\begin{array}{cccc}
M & 0 & 0 & -\frac{\beta S^{*}}{\left(1+\alpha V^{*}\right)^{2}} \\
\frac{\beta V^{*}}{\left(1+\alpha V^{*}\right)} & -G & 0 & \frac{\beta S^{*}}{\left(1+\alpha V^{*}\right)^{2}} \\
0 & \delta & -\left(d_{3}+K\right) & 0 \\
0 & n d_{1} & 0 & -d_{4}
\end{array}\right]
$$

yang memiliki persamaan karakteristik berbentuk

$$
\left(\lambda+d_{3}+K\right)\left(\lambda^{3}+a_{2} \lambda+a_{1} \lambda+a_{0}\right)=0,
$$

dengan akar-akar $\lambda_{1}=d_{3} K<0$ dan jika $a_{2}, a_{1}, a_{0}>0$ maka ketiga akar lainnya akan memiliki bagian real negatif. Dengan kata lain titik ekuilibrium kanker nasofaring $E_{2}$ stabil asimtotik lokal jika $a_{2}, a_{1}, a_{0}>0$.

\subsection{Simulasi numerik}

Untuk memverifikasi hasil teoritis pada sub bab sebelumnya, pada bagian ini diberikan simulasi numerik. Nilai-nilai parameter yang digunakan untuk simulasi diambil dari referensi $[7,10]$. Untuk menunjukkan kestabilan titik ekuilibrium E1, dipilih nilai-nilai parameter

$$
\begin{aligned}
\alpha & =0,01 ; r=1 ; p=0,05 ; \\
\beta & =0,1 ; \delta=0,0082 ; d_{1}=0,0138 ; \\
K & =0,1 ; d_{3}=0,0188 ; d_{4}=0,1152 ; n=2 .
\end{aligned}
$$

Dengan nilai-nilai parameter (3.5) tersebut diperoleh titik ekuilirium $E_{1}=$ $(18,0,0,0)$ dan $\beta n d_{1}(K-r)+d_{4} p r\left(d_{1}+\alpha+K\right)=4.646910^{-4}>0$ yang memenuhi kondisi pada Teorema 3.3. Dengan demikian $E_{1}=(18,0,0,0)$ stabil asimtotik lokal, seperti terlihat pada Gambar 2.

Gambar 2(a) merupakan solusi terhadap waktu yang menunjukkan sel terinfeksi, sel karsinoma invasif dan virus pada akhirnya akan hilang dari tubuh. Gambar 2(b) merupakan plot tiga dimensi dari sel terinfeksi, sel karsinoma invasif, dan virus yang menunjukkan kestabilan dari titik ekuilibrum bebas kanker nasofaring. Terlihat bahwa semua trayektori dari kondisi awal yang berbeda akan menuju ke kondisi lenyapnya ketiga populasi tersebut.

Berikutnya, diambil nilai parameter $\beta=0,16$ dan nilai parameter lainnya tetap seperti pada (3.5). Dengan nilai parameter tersebut, diperoleh titik ekuilibrium $E_{2}=(4,8028 ; 3,3355 ; 20,0463 ; 1,3837)$ dan memenuhi kondisi-kondisi pada Teorema 3.4, sehingga $E_{2}$ stabil asimtotik lokal.

Gambar 3(a) memperlihatkan dalam waktu sekitar 300 hari, jumlah populasi akan menuju ke titik ekuilibrium, sedangkan pada Gambar 3(b) titik ekuilibrium 

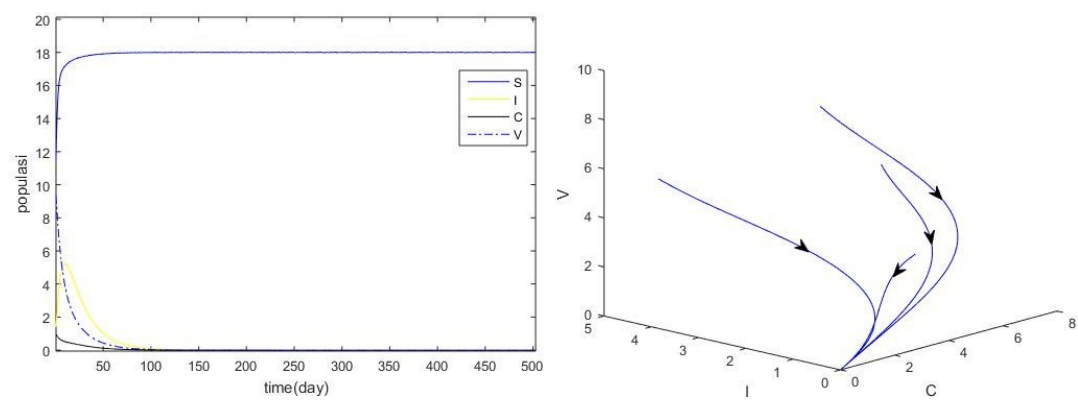

Gambar 2: Titik ekuilibrium bebas kanker nasofaring
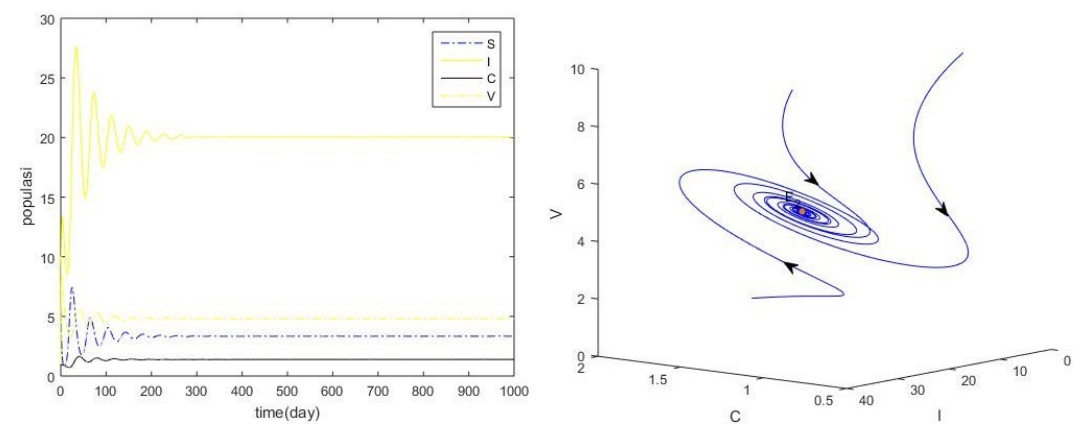

Gambar 3: Titik ekuilibrium kanker nasofaring

$E_{2}$ ini stabil asimtotik, seperti tampak bahwa semua trayektori yang dimulai dari kondisi awal berbeda akan menuju ke kondisi setimbang tersebut.

Untuk melihat pengaruh pemberian obat kemoterapi, pada Gambar 4 diberikan simulasi dengan variasi nilai $K$. Terlihat bahwa semakin besar nilai $K$, yang berarti dosis kemoterapi semakin besar, maka kemungkinan kondisi bebas kanker nasofaring dapat segera tercapai. Namun demikian, dari sisi medis tentu saja ada dosis maksimal yang diberikan untuk setiap pengobatan, sehingga penderita kanker nasofaring tidak mengalami overdosis. Pada Gambar 4(a), dengan nilai $K=0,078$ terlihat akan terjadi kanker nasofaring. Jumlah populasi sel akan menuju ke titik kesetimbangan kakner nasofaring dalam waktu sekitar dua tahun. Pada Gambar 4(b), dengan nilai $K=0,15$ kesetimbangan kanker akan tercapai lebih cepat, namun jumlah populasi sel kanker lebih sedikit. Sedangkan pada Gambar 4(c), dengan nilai $K=0,5$ memperlihatkan terjadinya kondisi bebas kanker. Penelitian lebih lanjut tentang dosis kemoterapi perlu dilakukan untuk memperoleh batasan maksimal dosis kemoterapi yang disarankan medis.

\section{Kesimpulan}

Pada artikel ini dipelajari model perkembangan sel kanker pada KNF, yang terdiri dari sel sehat orofaring, sel terinfeksi, sel invasif karsinoma, dan interaksinya dengan 

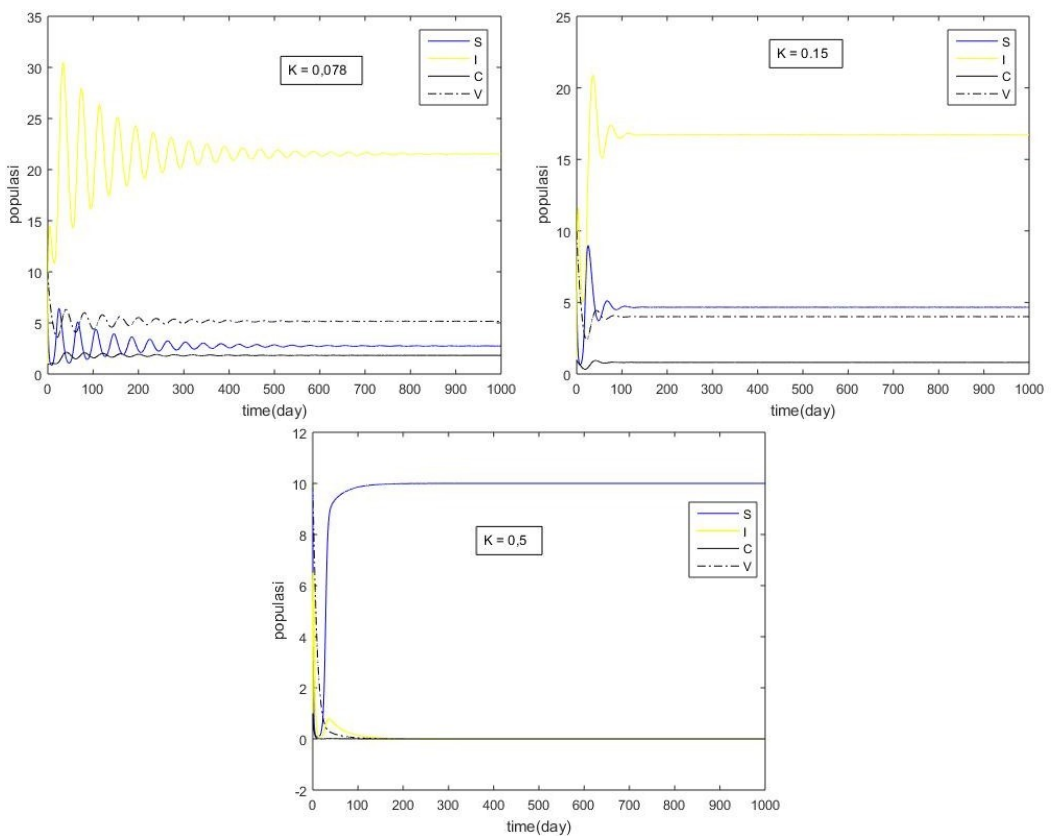

Gambar 4: Simulasi dengan variasi dosis kemoterapi

virus EBV. Dipertimbangkan juga pemberian dosis kemoterapi sebagai upaya pengobatan kanker. Dari model yang disusun selanjutnya dilakukan analisis kesatabilan titik ekuilibrium bebas kanker dan titik ekuilibrium kanker nasofaring. Laju pertumbuhan sel terinfeksi berpengaruh terhadap kondisi keberlangsungan kanker KNF. Dipelajari juga pengaruh pemberian dosis kemoterapi, yang menunjukkan semakin besar dosis kemoterapi makan kesembuhan akan dapat tercapai. Tentu saja dosis pemberian kemoterapi ada batas maksimalnya sehingga untuk menuju kesembuhan bukan berarti dosis kemoterapi dapat dibuat sebesar mungkin. Walaupun model yang disusun masih sederhana, namun diharapkan dapat menjadi dasar pemodelan kanker nasofaring terkait dengan keberadaan visus EBV dan upaya pengobatan dengan kemoterapi. Untuk penelitian selanjutnya perlu dipelajari lebih mendalam tentang perkembangan sel kanker nasofaring dan intervensi pengobatan yang mungkin dilakukan.

\section{Daftar Pustaka}

[1] Rahman, S., Budiman, B.J., Subroto, H., 2015, Faktor Risiko Non Viral Pada Karsinoma Nasofaring, Jurnal Kesehatan Andalas, Vol. 4, no.3, hal: 988 - 994

[2] Komite Penanggulangan Kanker Nasional Kemenkes RI, 2021.,Panduan Penatalaksanaan Kanker

Nasofaring, http://www.kanker.kemkes.go.id/guidelines/PPKNasofaring.pdf, ditemukenali 30 Mei 2021.

[3] Kartikasari, Y., Murniati, Sakur, M., 2021, Prosedur Pemeriksaan MRI Leher Pada Kasus Karsinoma Nasofaring Di Instalasi Radiologi RS Ken Saras Kabu- 
paten Semarang, Jurnal Imejing Diagnostik (JImeD), Vol 7, hal: 48 - 58

[4] Dewi,S.P., Handoko, Yudharto, M.A., Gondhowiardjo, S.S., 2020, Kadar Plasma Epstein-Barr Virus DNA sebagai Parameter Prognosis pada Kanker Nasofaring Tidak Berkeratin, Radioterapi dan Onkologi Indonesia, Vol 11, no. 1, hal: 17 23

[5] Susworo, R., 2004, Kanker Nasofaring Epidemiologi dan Pengobatan Mutakhir, CDK, PT. Kalbe Farma, hal: $16-19$

[6] Faiza, S.,Rahman, S., Asri, A., 2016, Faktor Risiko Non Viral Pada Karsinoma Nasofaring Karakteristik Klinis dan Patologis Karsinoma Nasofaring di Bagian THT-KL RSUP Dr. M. Djamil Padang, Jurnal Kesehatan Andalas, Vol. 5, no.1, hal: $90-96$

[7] Sugiyanto, 2016, A Stability Mathematical Model of Nasopharyngeal Carcinoma on Cellular Level, Biology, Medicine, Natural Product Chemistry, Vol 5, no. 2, hal: $61-64$

[8] Sudiono, J., Hassan, I., 2013, DNA Epstein-Barr virus (EBV) sebagai biomaker diagnosis karsinoma nasofaring, Dental Journal, vol 46, no. 3, hal: $140-147$

[9] Sugiyanto, Ndii, M. Z., 2019, Mathematical Modeling with T Cell in Nasofaringeal Carcinoma, Kaunia, vol 15, no. 2, hal: $43-47$

[10] Sugiyanto, Aryati, L., Adi-Kusumo, F., Hardianti, M.S., 2018, Link of Nasopharyngeal Carcinoma and Epstein-Barr Virus, Biology, Medicine, Natural Product Chemistry, Vol 7, no. 2, hal: $51-55$

[11] Perko, L. 2001, Differential equations and dynamical systems, Springer-Verlag, New York. 